\title{
Corticosteroid Treatment for Acute Meningoencephalitis : a Retrospective Study of 346 Cases
}

\author{
JOHS. BØE,* M.D. ; CLAUS OLA SOLBERG,† M.D. ; TRYGVE SæTER, $\ddagger$ M.D
}

Brit. med. F., 1965, 1, 1094-1095

The use of corticosteroids in the treatment of severe infectious diseases is still a controversial matter.

In the case of bacterial infections thorough investigations have been carried out, and the initial enthusiasm has been replaced by a more sceptical attitude. The urgent need for a controlled investigation was met by the Cooperative Study Group (1963), and the results of this study have probably contributed more than anything else to the change of opinion.

The results in viral infections are even more difficult to evaluate. Because of this, and also because of lack of effective antiviral treatment, corticosteroids are still in common use in many severe viral infections. They are used especially in the treatment of meningoencephalitis and other, more obscure, diseases of the nervous system (Foster, 1962). Theoretically there are indications both for and against the use of corticosteroids. They can enhance a viral infection in animals. On the other hand, they can inhibit the development of experimental allergic encephalomyelitis, a condition thought to have some features in common with the para-infectious or postinfectious meningoencephalitis in humans.

Publications on the clinical investigations of these drugs in meningoencephalitis are deficient in many ways. The literature is full of reports of favourable but uncontrolled observations in seemingly hopeless cases. These reports may in fact describe nothing more than the natural history of the disease. For obvious reasons the unsuccessful cases are not recorded; and since the individual physician sees only a few cases of meningoencephalitis it is difficult for him to reach any conclusion about the value of corticosteroid treatment.

Unfortunately there has been no double-blind study similar to that mentioned above for bacterial infections. A few investigators have tried to compare a group of corticoid-treated patients with a control group of untreated patients. Karelitz and Eisenberg (1961) studied 42 patients with measles encephalitis, 20 of whom were given A.C.T.H. and corticosteroids in varying doses. These authors raised serious doubts about the advisability of using these drugs in the management of measles encephalitis. Ziegra (1961) undertook a controlled study on 32 patients with measles encephalitis, half of them being treated with A.C.T.H., hydrocortisone, and cortisone in the dosage and regimen reported so favourably by Allen (1957). There was no apparent benefit related to corticosteroid therapy.

The present report is a retrospective study on 346 cases of meningoencephalitis, 106 of whom were comatose during the acute stage of the illness.

\section{Method of Study}

We had at our disposal the death certificates for all who died of acute meningoencephalitis in Norway from 1953 to 1960 - a period when corticosteroids were in common use. (In addition to number 082-acute encephalitis according to the

\footnotetext{
- Professor of Medicine and Chief of Medical Department B, University Hospital, University of Bergen School of Medicine.

t Research Fellow, Medical Department B, University Hospital, University of Bergen School of Medicine.

¥ Associate in Medicine, Medical Department B, University Hospital, University of Bergen School of Medicine.
}

International List of Death Certificates-we also scrutinized numbers $085,086,087$, and 089.) The certificates issued by hospitals from which adequate case histories and necropsy reports could be obtained were selected. Complete data for all surviving patients with the same diagnosis during the same period were obtained from the same hospitals. These hospitals covered practically the whole of Norway.

During this period 114 patients were reported dead from acute encephalitis and 440 survived. After a careful analysis of all available data 208 cases had to be omitted. In these cases the diagnosis acute meningoencephalitis could not be upheld according to strict criteria-that is, coma, convulsions, drowsiness, or motor or sensory signs of central nervous system involvement. In addition, normal cerebrospinal fluid or changes as for seromeningitis were required. In some cases the diagnosis was based on post-mortem examinations.

The material left for a final analysis consisted, therefore, of 346 patients.

The first group of 91 patients had post-infectious meningoencephalitis according to all criteria. The second group of 153 patients had acute meningoencephalitis, most certainly not post-infectious. A third group of 102 patients has been classified as "encephalitis" because, although the diagnosis acute meningoencephalitis seemed well founded, all criteria were not present in every case, and it was not always apparent if the meningoencephalitis was "post-infectious" or not. It can be seen from Table I that the mean age of the third group was nearer that of group 2 than that of group 1.

\begin{tabular}{|c|c|c|c|c|c|c|c|c|c|}
\hline \multirow{2}{*}{\multicolumn{2}{|c|}{ Diagnosis }} & \multirow[b]{2}{*}{$\begin{array}{l}\text { Total } \\
\text { No. }\end{array}$} & \multicolumn{3}{|c|}{ Survivors } & \multicolumn{3}{|c|}{ Dead } & \multirow{2}{*}{$\begin{array}{l}\text { Death } \\
\text { Rate } \\
\%\end{array}$} \\
\hline & & & F. & M. & $\begin{array}{c}\text { Mean } \\
\text { Age } \\
\text { (yrs.) }\end{array}$ & F. & M. & $\begin{array}{l}\text { Mean } \\
\text { Age } \\
\text { (yrs.) }\end{array}$ & \\
\hline $\begin{array}{l}\text { Encephalitis, post- } \\
\text { infectious }\end{array}$ & $\left\{\begin{array}{l}\text { Morbilli } \\
\text { Varicella } \\
\text { Rubeola } \\
\text { Parotitis }\end{array}\right.$ & $\begin{array}{l}40 \\
21 \\
20 \\
10\end{array}$ & $\begin{array}{l}9 \\
9 \\
4 \\
2\end{array}$ & $\begin{array}{r}14 \\
8 \\
10 \\
6\end{array}$ & & $\begin{array}{l}6 \\
1 \\
3 \\
0\end{array}$ & $\begin{array}{r}11 \\
3 \\
3 \\
2\end{array}$ & & $\begin{array}{l}42 \cdot 5 \\
19 \\
30 \\
20\end{array}$ \\
\hline $\begin{array}{l}\text { Encephalitis, not pos } \\
\text { Encephalitis, uncerta }\end{array}$ & $\begin{array}{l}\text { Total } \\
\text { t-infectious } \\
\text { in }\end{array}$ & $\begin{array}{r}91 \\
153 \\
102\end{array}$ & $\begin{array}{l}24 \\
61 \\
30\end{array}$ & $\begin{array}{l}38 \\
59 \\
41\end{array}$ & $\begin{array}{r}7 \cdot 3 \\
22 \cdot 2 \\
20 \cdot 9\end{array}$ & $\begin{array}{l}10 \\
15 \\
12\end{array}$ & $\begin{array}{l}19 \\
18 \\
19\end{array}$ & $\begin{array}{l}7.0 \\
21 \\
16 \cdot 6\end{array}$ & $\begin{array}{l}32 \\
21 \cdot 5 \\
30\end{array}$ \\
\hline
\end{tabular}

Treatment.-Practically all patients received antibiotics and other supportive treatment; 77 patients received corticosteroid therapy, the daily doses ranging between 75 and $300 \mathrm{mg}$. cortisone. For the patients who died the length of treatment varied from half a day to 11 days (nine of them for as long as 5 to 11 days). The treatment, including corticosteroids, did not differ in any appreciable manner for those who survived and those who did not.

\section{Results}

Table II shows the effect of corticosteroid treatment on mortality in the whole material. It is apparent that in all three groups the mortality is higher in treated than in untreated patients.

If only the comatose patients are considered (to allow for the possibility that steroids were more often given to severely 
ill patients) the results are found to be the same (Table III)that is, the mortality is higher among the patients receiving corticosteroids.

TABLE II.-Bffect of Corticosteroid Treatment on Mortality : All Patients

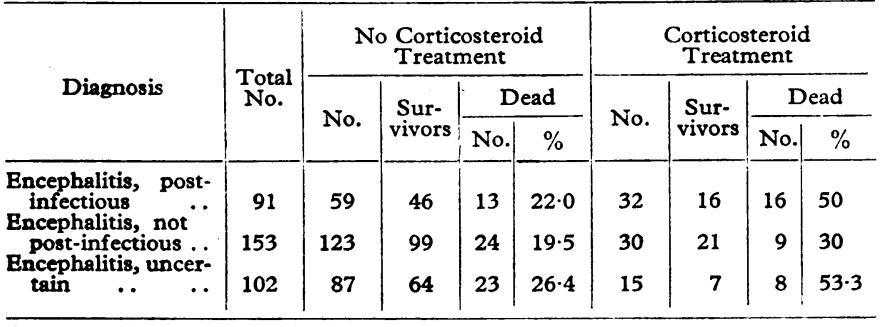

Table III.-Effect of Corticosteroid Treatment on Mortality : Patients

\begin{tabular}{|c|c|c|c|c|c|c|c|c|c|}
\hline \multirow{3}{*}{ Diagnosis } & \multirow{3}{*}{$\begin{array}{l}\text { Total } \\
\text { No. }\end{array}$} & \multicolumn{4}{|c|}{$\begin{array}{c}\text { No Corticosteroid } \\
\text { Treatment }\end{array}$} & \multicolumn{4}{|c|}{$\begin{array}{c}\text { Corticosteroid } \\
\text { Treatment }\end{array}$} \\
\hline & & \multirow{2}{*}{ No. } & \multirow{2}{*}{$\begin{array}{l}\text { Sur- } \\
\text { vivors }\end{array}$} & \multicolumn{2}{|c|}{ Dead } & \multirow{2}{*}{ No. } & \multirow{2}{*}{$\begin{array}{l}\text { Sur- } \\
\text { vivors }\end{array}$} & \multicolumn{2}{|c|}{ Dead } \\
\hline & & & & No. & $\%$ & & & No. & $\%$ \\
\hline \multirow{3}{*}{$\begin{array}{c}\text { Encephalitis, post- } \\
\text { infectious } \\
\text { Encephalitis, not } \\
\text { post-infectious .. }\end{array}$} & 50 & 29 & 13 & 16 & $55 \cdot 2$ & 21 & 8 & 13 & 61.9 \\
\hline & 56 & 38 & 15 & 23 & $60 \cdot 5$ & 18 & 4 & 14 & $77 \cdot 8$ \\
\hline & & 67 & 28 & 39 & $58 \cdot 2$ & 39 & 12 & 27 & $69 \cdot 2$ \\
\hline
\end{tabular}

The frequency of neurological sequelae on discharge from hospital among the 40 surviving patients who were comatose during the acute illness is shown in Table IV. With due regard to the small number of cases the frequency of sequelae was distinctly higher in the treated groups.

TABLB IV.-Effect of Corticosteroid Treatment on Neurological Sequelae in 40 Bncephalitis Patients Who Were Comatose During the Acute Illness

\begin{tabular}{|c|c|c|c|c|c|c|}
\hline & \multicolumn{3}{|c|}{ No Corticosteroid Treatment } & \multicolumn{3}{|c|}{ Corticosteroid Treatment } \\
\hline & \multirow{2}{*}{ No. } & \multicolumn{2}{|c|}{ Sequelae } & \multirow{2}{*}{ No. } & \multicolumn{2}{|c|}{ Sequelae } \\
\hline & & Absent & Present & & Absent & Present \\
\hline $\begin{array}{l}\text { Encephalitis, } \\
\text { post-infectious.. } \\
\text { Encephalitis, not } \\
\text { pest-infectious }\end{array}$ & $\begin{array}{l}14 \\
15\end{array}$ & $\begin{array}{l}10 \\
11\end{array}$ & $\begin{array}{l}4(28.6 \%) \\
4(26.6 \%)\end{array}$ & $\begin{array}{l}7 \\
4\end{array}$ & $\begin{array}{l}2 \\
1\end{array}$ & $\begin{array}{ll}5 & (71 \%) \\
3 & (75 \%)\end{array}$ \\
\hline & 29 & 21 & $8(27 \cdot 6 \%)$ & 11 & 3 & $8(73 \%)$ \\
\hline
\end{tabular}

\section{Discussion}

The clinical picture in post-infectious meningoencephalitis is very variable. Thị makes it extremely difficult, during the acute stage of the illness, to predict the further course in each individual case. The mortality figures are, however, fairly well known and have been discussed in a comprehensive review by Miller et al. (1956). With the best supportive treatment now available (oxygen, electrolyte and fluid balance, antibiotics for bacterial complications, gamma-globulin, etc.) the mortality may have decreased during recent years. The series of Karelitz and Eisenberg (1961) of 42 consecutive cases of measles encephalitis without a single death is, however, unusual.
In the present series the mortality rates are higher than those usually reported, indicating that we have been fairly strict with the diagnosis, including only cases with the complete clinical picture. This does not detract from the value of the material for the purpose of the present investigation. It is commonly agreed that if corticosteroids are to be used at all they should certainly be used in the severe cases.

Looking at the material as a whole the results seem clear. It is shown that in every group the patients who were not treated with corticosteroids fared better than those who received them.

It is possible that corticosteroids have been used more extensively in the severe cases. A separate analysis has therefore been made of the patients who were comatose during the acute stage of the illness. Certainly they were "ill enough" to have whatever treatment was available. The results are clear also in this group. 'There was no benefit from corticosteroids. If any conclusion can be reached it is that the mortality was higher in the corticosteroid-treated groups.

Clinical impressions could naturally be discussed at length when dealing with so many patients. We will, however, mention only that in two or three cases a "dramatic effect" from corticosteroid treatment was observed. On the other hand, we know. of three or four cases where corticosteroids seem to have had a deleterious effect.

The effect of corticosteroid treatment on the frequency of neurological sequelae, as shown in Table IV, was very disappointing. The frequency of sequelae was naturally high among patients who were comatose during the acute stage, but, in whatever way we look at it, neurological sequelae occurred more often in the corticosteroid-treated groups.

\section{Summary}

A retrospective study is reported of the effect of corticosteroid treatment in acute meningoencephalitis in 346 patients : 91 had post-infectious meningoencephalitis, 153 were regarded as not post-infectious, and in 102 the diagnosis was more uncertain.

In all three groups the mortality rates were higher in the patients who were treated with corticosteroids.

The 106 patients who were comatose during the acute stage of the illness were analysed separately. The results were the same: the patients who received no corticosteroids fared better than those who were treated with corticosteroids.

The frequency of neurological sequelae was higher in the corticosteroid-treated patients.

\section{REFERENCES}

Allen, J. E. (1957). Pediatrics, 20, 87.

Cooperative Study Group' (1963). F. Amer. med. Ass., 183, 462.

Foster, J. B. (1962). In Modern Trends in Neurology, edited by D. Williams, 3rd series, p. 292. Butterworths, London.

Karelitz, S., and Eisenberg, M. (1961). Pediatrics, 27, 811.

Miller, H. G., Stanton, J. B., and Gibbons, J. L. (1956). Quart. F. Med., $25,427$.

Ziegra, S. R. (1961). Э. Pediat., 59, 322. 